\title{
Organic Compounds in Paper and Plastic Food Packaging
}

\author{
Li XIE ${ }^{1, a,{ }^{*}}$, Jiang YU ${ }^{1, b}$, Lu PEI ${ }^{1, c}$, Xing ZHOU ${ }^{1, d}$, Lu REN ${ }^{1, e}$ \\ ${ }^{1}$ Institute of Printing and Packaging Engineering, Xi' an University of Technology, Xi' an, Shaanxi \\ 710048, China \\ axnxieli@126.com, byupp@126.com, ${ }^{\mathrm{c}}$ peilu11@126.com, ${ }^{\mathrm{d}}$ zhouxing61@163.com, \\ renlu123@163.com \\ ${ }^{*}$ Corresponding author
}

Keywords: Food Paper Packaging, Plastic Bag, Organic Compound.

\begin{abstract}
Additives, printing ink and other chemicals in packaging may influence safety of the food. Standard solutions of eight organic compounds were prepared. By gas chromatography and mass spectrometry technology, benzene, isopropyl alcohol, ethyl acetate, ethyl benzene, cyclohexanone, $m / p$-Xylene, $o$-Xylene and butyl acetate in biscuit paper carton and jujube plastic bag were determined and analyzed. Linear calibration curves of the eight compounds were obtained with correlation coefficients of more than 0.9827 , detection limits were in the range of $0.003-0.009 \mathrm{mg} / \mathrm{m}^{2}$, recoveries ranged from $84 \%$ to $96 \%$ with RSD less than $3.8 \%$. The results show that organic compounds in biscuit paper carton and jujube plastic bag are respectively $0.266 \mathrm{mg} / \mathrm{m}^{2}$ and 0.37 $\mathrm{mg} / \mathrm{m}^{2}$. Benzenes in the two packages are respectively $0.167 \mathrm{mg} / \mathrm{m}^{2}$ and $0.289 \mathrm{mg} / \mathrm{m}^{2}$. Content of benzenes in the gravure printing inks used in the jujube plastic bag is obviously much more than that in the offset printing inks used in the biscuit paper carton.
\end{abstract}

\section{Introduction}

Plastic is polymer material made from synthetic resin monomer as raw material, adding an appropriate amount of stabilizers, plasticizers, antioxidant, coloring, pesticides and preservatives in process [1]. Due to light weight, convenient transportation and sales, good chemical stability, easy processing, good adornment effect and ideal protection effect, plastic packaging materials are widely used in food industry. However, there are some problems in terms of health and safety in food plastic packaging materials. The problems mainly are harmful monomer, oligomers, additives and organic compounds produced in process. These poisonous and harmful chemical pollutants may dissolute and migrate from packaging materials, resulting in contamination of food. Eventually, they may cause harm to people's physical and mental health.

During manufacturing process of paper packaging materials, there are wax, fluorescent whitening agent, sizing agent, organic chloride, curing agent, fungicide, organic solvents and surfactant. These compounds may migrate from materials to food.

There are a lot of harmful solvents such as benzene, toluene, xylene, ethyl acetate, butyl acetate, isopropyl alcohol, n-propyl acetate and n-butyl acetate in solvent-based printing inks. Among them, benzene solvents may cause greatest harm to human [2,3].

Scholars in domestic and foreign countries have made some researches on harmful compounds in food packaging materials [4-13]. In this paper, a gas chromatography and mass spectrometry method is used to analyze organic compounds in offset printed biscuit paper box and gravure printed jujube plastic bag in order to manufacture safe and reliable food packaging.

\section{Experiment}

\section{Sample Preparation}

Biscuit paper box, white cardboard, offset printing ink: yellow ink, magenta ink, cyan ink and black ink, fountain solution; jujube plastic bag, polyethylene (PE), polyester (PET), gravure printing ink: 
yellow ink, magenta ink and cyan ink, binder. These materials were provided by Xi'an ZhiCheng packaging company. $5 \mathrm{~cm} \times 5 \mathrm{~cm}$ of packaging materials were clipped in accordance with location of printing pattern, manually cut into strips with dimensions of $5 \mathrm{~cm} \times 0.5 \mathrm{~cm}$. Then these strips were put into headspace bottles. About $5 \mathrm{mg}$ of printing ink, fountain solution and binder were put into headspace bottles respectively. The headspace bottles were put into headspace equipment to test.

\section{Chemicals and Standard Solutions}

Benzene, isopropyl alcohol, ethyl acetate, ethyl benzene, cyclohexanone, $m / p$-Xylene, butyl acetate and $o$-Xylene, (purity $>99 \%$, Tianjin, China) were prepared. Standard solutions of the eight reagents in methyl alcohol at a series density of standard solution $(0.01 \%, 0.02 \%, 0.04 \%, 0.05 \%, 0.06 \%, 0.08 \%$, $0.1 \%$ ) were obtained for external calibration.

\section{Equipment and Chromatographic Conditions}

Headspace gas chromatography and mass spectrometry system (Clarus 600, PerkinElmer, USA) fitted with TurboMass software was used for experiment and data acquisition.

Balance temperature was $85^{\circ} \mathrm{C}$, balance time was $40 \mathrm{~min}$. Oven temperature was held at $35^{\circ} \mathrm{C}$ for 6 min, then raised at $18{ }^{\circ} \mathrm{C} / \mathrm{min}$ up to $210{ }^{\circ} \mathrm{C}$; carrier gas, $\mathrm{He}$ (purity>99.999\%) at a constant flow rate of $2.0 \mathrm{~mL} / \mathrm{min}$.

MS conditions were as follows: ion source temperature, $210{ }^{\circ} \mathrm{C}$; Interface temperatures, $220{ }^{\circ} \mathrm{C}$. Quality scan range: $m / z$ 35-400; ion source voltage, $70 \mathrm{eV}$.

\section{Results and Discussion}

\section{Determination of Standard Sample}

Standard solutions of $1 \mu \mathrm{L}$ were spiked into headspace bottles to test compound under the experimental conditions. Fig. 1 shows retention time of isopropyl alcohol, ethyl acetate, benzene, butyl acetate, ethyl benzene, $\mathrm{m} / \mathrm{p}$-xylene, $o$-xylene and cyclohexanone is respectively $1.79 \mathrm{~min}, 2.51$ min, $3.03 \mathrm{~min}, 6.20 \mathrm{~min}, 6.86 \mathrm{~min}, 6.99 \mathrm{~min}, 7.31 \mathrm{~min}$ and $7.39 \mathrm{~min}$. Peak area as vertical coordinate, quantity concentration of compound as horizontal coordinate, regression equations of the eight compounds were calculated. Linear calibration curves of the eight compounds were obtained with correlation coefficients of more than 0.9827 , detection limits were in the range of $0.003-0.009 \mathrm{mg} / \mathrm{m}^{2}$, recoveries ranged from $84 \%$ to $96 \%$ with RSD less than $3.8 \%$. The results are shown in Table 1 .

Tab. 1 Regression equations, correlation coefficients, detection limits and relative standard deviations of compounds

\begin{tabular}{cccccc}
\hline Compound & $\begin{array}{c}\text { Regression } \\
\text { equation }\end{array}$ & $\begin{array}{c}\text { Correlation } \\
\text { coefficient }\end{array}$ & $\begin{array}{c}\text { Detection } \\
\text { limit }\left(\mathrm{mg} / \mathrm{m}^{2}\right)\end{array}$ & $\begin{array}{c}\text { Recovery } \\
(\%)\end{array}$ & RSD (\%) \\
\hline $\begin{array}{c}\text { Isopropyl } \\
\text { alcohol }\end{array}$ & $y=532.45 x-784.12$ & 0.9896 & 0.004 & 91 & 2.5 \\
Ethyl acetate & $y=267.236 x-34.56$ & 0.9937 & 0.003 & 89 & 2.8 \\
Benzene & $y=38.74 x-3681.4$ & 0.9985 & 0.005 & 84 & 2.6 \\
Butyl acetate & $y=86.452 x-542.52$ & 0.9939 & 0.004 & 90 & 2.9 \\
Ethylbenzen & $y=134.257 x-236.4$ & 0.9827 & 0.006 & 87 & 3.8 \\
e & $y=89.54 x-5413.21$ & 0.9864 & 0.005 & 85 & 3.2 \\
$\begin{array}{c}m / p \text {-Xylene } \\
o \text {-Xylene }\end{array}$ & $y=76.255 x-453.9$ & 0.9853 & 0.009 & 94 & 3.1 \\
Cyclohexane & $y=564.213 x-541.8$ & 0.9961 & 0.004 & 96 & 2.7 \\
\hline
\end{tabular}




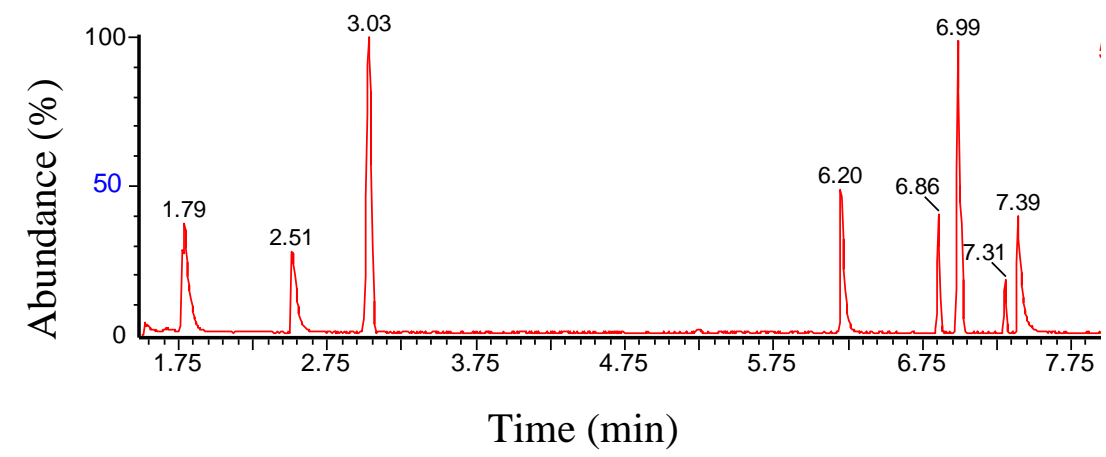

Fig. 1 Chromatogram of standard solution

\section{Organic Compound in Food Packaging and Its Raw Materials}

Chromatograms of paper carton and plastic bag are shown in Fig. 2 and Fig. 3. Content of the compounds was calculated by regression equation. The results are shown in Table 2 and Table 3 .

Tab.2 Organic compounds in the paper carton and its raw materials

\begin{tabular}{cccccccccc}
\hline Sample & $\begin{array}{c}\text { Isopropyl } \\
\text { alcohol }\end{array}$ & $\begin{array}{c}\text { Ethyl } \\
\text { acetate }\end{array}$ & $\begin{array}{c}\text { Butyl } \\
\text { acetate }\end{array}$ & $\begin{array}{c}\text { Benzen } \\
\mathrm{e}\end{array}$ & $\begin{array}{c}\text { Ethyl } \\
\text { benzene }\end{array}$ & $\begin{array}{c}\mathrm{m} / \mathrm{p}- \\
\text { Xylene }\end{array}$ & $\begin{array}{c}o \text { - } \\
\text { Xylene }\end{array}$ & $\begin{array}{c}\text { Cyclohe } \\
\text { xanone }\end{array}$ & Amount \\
\hline $\begin{array}{c}\text { White } \\
\text { cardboard } \\
\left(\mathrm{mg} / \mathrm{m}^{2}\right)\end{array}$ & 0.050 & 0.047 & 0.002 & 0.014 & 0.045 & 0.051 & 0.092 & - & 0.301 \\
$\begin{array}{c}\text { Yellow ink } \\
(\mathrm{mg} / \mathrm{kg})\end{array}$ & 11.256 & 0.112 & 0.024 & 0.127 & 0.320 & 0.378 & 0.750 & - & 12.967 \\
$\begin{array}{c}\text { Magenta ink } \\
(\mathrm{mg} / \mathrm{kg})\end{array}$ & 3.400 & 0.080 & 0.026 & 0.333 & 0.233 & 0.260 & 0.630 & - & 4.962 \\
$\begin{array}{c}\text { Cyan ink } \\
(\mathrm{mg} / \mathrm{kg})\end{array}$ & 10.986 & 0.290 & 0.042 & 1.381 & 0.769 & 0.577 & 2.628 & - & 16.673 \\
$\begin{array}{c}\text { Black ink } \\
(\mathrm{mg} / \mathrm{kg})\end{array}$ & 18.490 & 0.341 & 0.095 & 0.372 & 1.170 & 1.006 & 1.974 & - & 23.448 \\
$\begin{array}{c}\text { Fountain } \\
\text { solution } \\
(\mathrm{mg} / \mathrm{kg})\end{array}$ & 102.237 & 0.150 & 0.016 & 0.073 & 5.223 & 1.051 & 2.441 & - & 111.191 \\
$\begin{array}{c}\text { Paper carton } \\
\left(\mathrm{mg} / \mathrm{m}^{2}\right)\end{array}$ & 0.055 & 0.042 & 0.002 & 0.011 & 0.038 & 0.040 & 0.078 & - & 0.266 \\
\hline
\end{tabular}

-: No detected

Table 3 Organic compounds in the jujube plastic bag and its raw materials

\begin{tabular}{cccccccccc}
\hline Sample & $\begin{array}{c}\text { Isopropyl } \\
\text { alcohol }\end{array}$ & $\begin{array}{c}\text { Ethyl } \\
\text { acetate }\end{array}$ & $\begin{array}{c}\text { Butyl } \\
\text { acetate }\end{array}$ & Benzene & $\begin{array}{c}\text { Ethyl } \\
\text { benzene }\end{array}$ & $\begin{array}{c}\mathrm{m} / p^{-} \\
\text {Xylene }\end{array}$ & $\begin{array}{c}o- \\
\text { Xylene }\end{array}$ & $\begin{array}{c}\text { Cyclohe } \\
\text { xanone }\end{array}$ & Amount \\
\hline $\begin{array}{c}\text { PET } \\
\left(\mathrm{mg} / \mathrm{m}^{2}\right)\end{array}$ & 0.042 & 0.016 & 0.002 & 0.007 & 0.018 & 0.019 & 0.020 & - & 0.124 \\
$\mathrm{PE}\left(\mathrm{mg} / \mathrm{m}^{2}\right)$ & 0.042 & 0.018 & 0.002 & 0.007 & 0.019 & 0.022 & 0.026 & - & 0.136 \\
$\begin{array}{c}\text { Yellow ink } \\
(\mathrm{mg} / \mathrm{kg})\end{array}$ & 73.284 & $\begin{array}{c}1637.4 \\
51\end{array}$ & 37.612 & 35.235 & 40.746 & 33.847 & 77.493 & - & 1935.668 \\
$\begin{array}{c}\text { Magenta ink } \\
(\mathrm{mg} / \mathrm{kg})\end{array}$ & 141.271 & $\begin{array}{c}442.16 \\
6\end{array}$ & 8.737 & 3.254 & 0.085 & $\begin{array}{c}205.37 \\
6\end{array}$ & 0.067 & 2531.56 & 3332.516 \\
$\begin{array}{c}\text { Cyan ink } \\
(\mathrm{mg} / \mathrm{kg})\end{array}$ & 45.134 & 0.178 & 2.163 & 90.857 & 0.258 & $\begin{array}{c}355.24 \\
0\end{array}$ & $\begin{array}{c}1348.7 \\
18\end{array}$ & - & 1842.548 \\
$\begin{array}{c}\text { Binder } \\
(\mathrm{mg} / \mathrm{kg})\end{array}$ & 3.411 & 0.028 & 0.122 & 0.017 & 0.534 & 0.695 & 0.860 & - & 5.667 \\
$\begin{array}{c}\mathrm{Plastic} \mathrm{bag} \\
\left(\mathrm{mg} / \mathrm{m}^{2}\right)\end{array}$ & 0.042 & 0.037 & 0.002 & 0.011 & 0.050 & 0.056 & 0.172 & - & 0.37 \\
\hline
\end{tabular}

-: No detected 


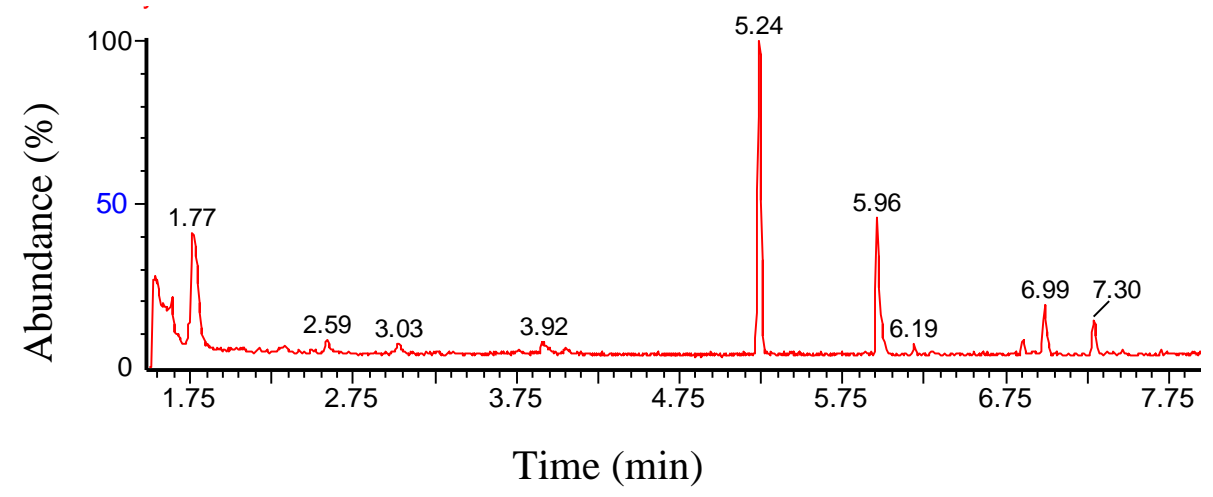

Fig. 2 Chromatogram of paper carton

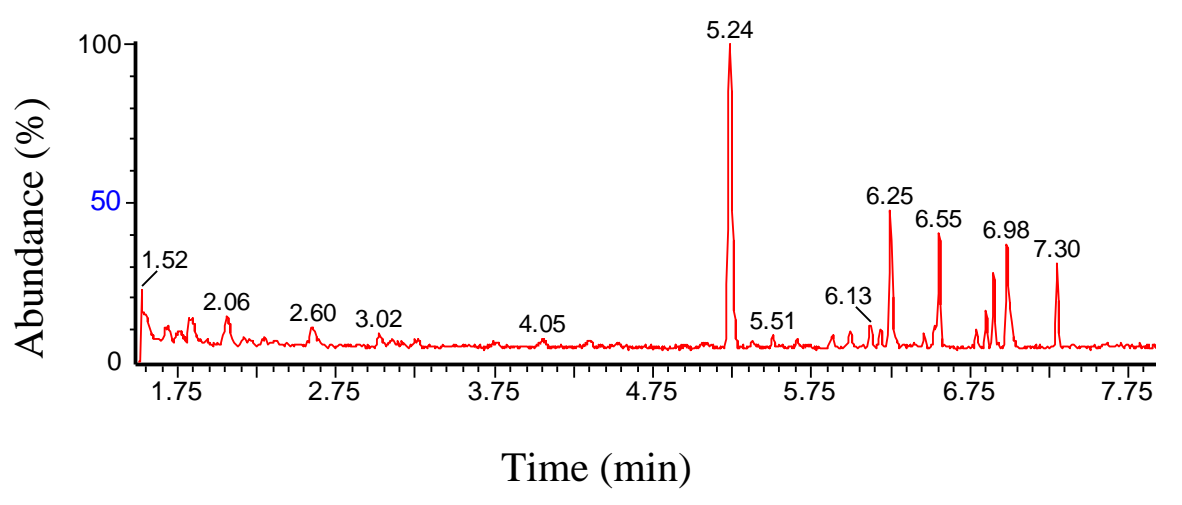

Fig. 3 Chromatogram of plastic bag

\section{Analysis of Organic Compound in Food Packaging}

Table 2 and table 3 show organic compounds in biscuit paper carton and jujube plastic bag are spectively $0.266 \mathrm{~g} / \mathrm{m}^{2}$ and $0.37 \mathrm{~g} / \mathrm{m}^{2}$. Benzenes in the two packages are respectively $0.167 \mathrm{mg} / \mathrm{m}^{2}$ and $0.289 \mathrm{mg} / \mathrm{m}^{2}$. Benzenes in yellow, magenta, cyan and black offset printing ink are respectively 1.575 $\mathrm{mg} / \mathrm{kg}, 1.456 \mathrm{mg} / \mathrm{kg}, 5.355 \mathrm{mg} / \mathrm{kg}$ and $4.522 \mathrm{mg} / \mathrm{kg}$. Benzenes in yellow, magenta and cyan gravure printing ink are respectively $187.321 \mathrm{mg} / \mathrm{kg}, 208.782 \mathrm{mg} / \mathrm{kg}$ and $1795.073 \mathrm{mg} / \mathrm{kg}$. Content of benzenes in gravure printing ink is obviously much more than that in offset printing ink. In addition, white cardboard, PET, PE, fountain solution and binder contain different degree of benzenes.

\section{Ways of Reducing Benzenes in Food Packaging}

In paper and plastic packaging, benzenes exist in basic material, printing ink, fountain solution and binder. Therefore, reducing benzenes organic compound mainly lays in the processing of raw materials and improving production process.

Print Packaging with Water-based Ink. There are not volatile organic solvents in water-based ink. So, printing with water-based ink can reduce residual toxicity in the printing products and make printing equipment easy to clean. Moreover, it can reduce fire risk and hazards due to static electricity and flammable solvents. Water-based ink is "green" printing material.

Print Paper Carton by Waterless Offset Printing Technology. Ink and fountain solution in traditional offset printing technology contain various organic solvents. Waterless offset printing technology commonly prints material with soybean oil ink and aromatic-free ink, which have no impact on human and environment. So, waterless offset printing technology, prints with non-solvent-based ink instead of fountain solution, make a great contribution to environment protection. 
Print Plastic Bag by Flexible Printing Technology. At present, food packaging in China is mainly printed by gravure technology. Various food packaging bags in supermarket, such as biscuit, pastry and milk powder packages, are basically printed with chlorinated polypropylene ink. While flexible printing is a main method of food packaging in Europe and other countries. Flexible printing is not as good as gravure printing in network performance. But it takes the lead in environment protection. Flexible printing will gradually replace gravure technology in the future development.

\section{Conclusions}

Organic compounds in biscuit paper carton, jujube plastic bag and their raw materials have been successfully analyzed by gas chromatography and mass spectrometry technology. Effective methods to reduce benzenes in the food packages have been put forward from the aspect of material and process.

\section{Acknowledgment}

This research was financially supported by the Foundation of Xi' an science and technology plan project, China (Project No. CXY1433(7)).

\section{References}

[1] Y.W. Liao, G.R. Cao, W.C. Xu, Discussion on the food safety issue of the plasticizer in lid gasket, Packaging Engineering, 29 (2008) 228-231.

[2] Z. Du, F.J Song, Discussion on relationship between hazard classification and health situation in benzene workers of petro-chemical enterprise, Chinese Journal of Industrial Medicine, 28 (2015) 63-64.

[3] Y.M, Ding, D.J. Gong, M.H. Yang, Investigation on occupational hazard of benzene series in industrial enterprises in Zhonglou District of ChangZhou City, Occupation and Health, 30 (2014) 2055-2057.

[4] S.H. Zhou, Q.B. Lin, B. Li, Determination of 18 substances in polypropylene food packaging materials by gas chromatography-mass spectrometry, Packaging and Food Machinery, 33 (2015) $56-62$.

[5] Y.N. Jiao, L. Ding, J.Y. Xiao, Simultaneous determination of multiple harmful substances in food plastic packing materials by gas chromatography-mass spectrometry, Journal of Food Safety and Quality, 4 (2013) 981-987.

[6] J. Muncke, Hazards of food contact material: food packaging contaminants, Encyclopedia of Food Safety, 2 (2014) 430-437.

[7] M. Aznar, C. Domeno, C. Nerin, Set-off of non volatile compounds from printing inks in food packaging materials and the role of lacquers to avoid migration, Dyes and Pigments, 114 (2015) 85-92.

[8] J.J. Zhu, J.E. Hill, Detection of escherichia coli via VOC profiling using secondary electrospray ionization-mass spectrometry (SESI-MS), Food Microbiology, 34 (2013) 412-417.

[9] P. Trefz, S. Kischkel, D. Hein, Needle trap micro-extraction for VOC analysis: effects of packing materials and desorption parameters, Journal of Chromatography A, 1219 (2012) 29-38.

[10] F. Biasioli, C. Yeretzian, F. Gaseri, PTR-MS monitoring of VOCs and BVOCs in food science and technology, Trends in Analytical Chemistry, 30 (2011) 968-977. 
[11] L. Xie, J. Yu, P.G. Ren, Analysis of volatile organic compounds in printing and plastic packaging materials of instant noodles by headspace gas chromatography-mass spectrometry, Chinese Journal of Analytical Chemistry, 39 (2011) 1368-1372.

[12] L. Xie, D.P. Jia, J.H. Ci, Analysis of volatile organic compounds in heatable plastic food packages, Packaging Engineering, 35 (2014) 34-37.

[13] C.B. Liu, Z.H. Liu, Z.Y. Sun, Analysis of volatile organic compounds in food packing material by purge \& trap-gas chromatography, Modern Scientific Instruments, 4 (2010) 87-89. 